\title{
REUSE OF SOLID WASTE IN A STEEL COMPANY FROM MINAS GERAIS: PROCESS, BENEFITS AND RESTRICTIONS
}

\author{
Igor de Oliveira Santos ${ }^{1}$, Elvis Denner Bicalho Pereira ${ }^{2}$, Jeane de Fátima da Cunha Brandão ${ }^{3}$ and \\ Isac Jonatas Brandão ${ }^{4}$
}

\author{
${ }^{1}$ State University of Minas Gerais - UEMG. Frutal-Minas Gerais, Brazil. \\ ${ }^{2,3}$ State University of Minas Gerais - UEMG. João Monlevade-Minas Gerais, Brazil. \\ ${ }^{4}$ University Center - UNIFACIG. Manhuaçu-Minas Gerais, Brazil.
}

Email: igordeoliveirasantos@hotmail.com, elvis.denner@outlook.com, jeanefcunha@yahoo.com.br, isacbrand@yahoo.com.br

Received: Dec $10^{\text {th }}, 2019$

Accepted: Jan $23^{\text {th }}, 2020$

Published: February $10^{\text {th }}, 2020$

Copyright @2016 by authors and Galileo Institute of Technology and Education of the Amazon (ITEGAM).

This work is licensed under the Creative Commons Attribution International License (CC BY 4.0).

https://creativecommons.org/licen ses/by/4.0/

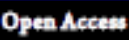

\begin{abstract}
The objective of this research was to conduct a study on the process of formation of recyclable raw material (RRM) in a company from the steel sector, pointing out the benefits and limitations of its reuse in the manufacturing process of liquid pig iron. For this purpose, bibliographic research and field visits were carried out. Waste generated throughout the company's steelmaking process is collected daily by a service company, where it undergoes beneficiation, forming the RRM. RRM is returned to the industry in order to be reused in its production process, configuring thus an operation of reverse logistics. RRM is used in order to reduce the use of iron ore in sinter production. This reduces the direct costs of iron ore extraction, transportation and storage and environmental impacts such as water, air and noise pollution. Other externalities are also avoided, such as land use conflicts, depreciation of surrounding properties, degradation of land and disruption to urban traffic. The results show that, in addition to environmental gains, the use of RRM generates savings of R $\$ 767.604,00$ per month to the industry. One of the limitations is that, concerning the manufacturing of special steels, there is risk of contamination and loss of quality if RRM is used in large proportions. It, however, is still an option for this sector on the pursuit of sustainability.
\end{abstract}

Keywords: Pig iron, Recyclable raw material, Iron ore, Economy.

\section{INTRODUCTION}

The Brazilian National Environmental Council, in Article number 2 of Resolution Number 313 from October 29, 2002, defines industrial solid waste as any waste that results from industrial activities and that is found in solid, semi-solid, gaseous when contained - and liquid states, whose particularities make it impossible for it to be discharged into the public sewage system or bodies of water, or that require technically or economically unfeasible solutions regarding the best available technology [1].

This type of waste has been the focus of great interest and has become important in the environmental, industrial, economic and academic scenarios, since large volumes are generated annually both in Brazil and worldwide.

Treatment of industrial waste prior to disposal, as well as recycling, reduces the impacts on the environment and on human health. Therefore, Brazilian legislation requires companies to create programs aimed at sustainable management of this waste.
In Brazil there are still many obstacles in its management, such as the lack of accurate information about quantities generated in the industrial sphere and about disposal and reuse [1].

An important tool created by Law 12.305, which governs the National Policy of Solid Waste, is reverse logistics. This is a crucial instrument in economic and social development, since it is guided by a series of actions and procedures aimed at enabling the collection and the return of solid waste to its process of origin for reuse in its own or in another production cycle or to some other appropriate destination.

Several organizations have been updating their production processes in light of this new reality, bringing several advantages for society and the environment, such as the return of solid waste to its sources or processes of origin, avoiding the contamination of soil and bodies of water and the degradation of air quality.

Further important points of the National Solid Waste Policy are the creation and consolidation of a shared responsibility system, of waste sorting and the update of production processes 
with the creation of cleaner processes that will facilitate reuse, creating products that are more easily inserted in reverse logistics.

With regard to the generation of industrial waste, the steel industry stands out in this aspect since it generates several types of waste in large quantities. Much of this waste, however, can be incorporated back into the productive chain.

In the sintering process the steel industry generates sintering fines and ore fines. In the blast furnace there is generation of blast furnace slag, ore fines, dust from the blast furnace's gas scrubbing system and from the dust removal system. In the steel mill, slag, dust from dust removal systems and gas scrubbing systems are generated. In the rolling stage, steel scrap and mill scale are generated, among other residues generated directly or indirectly from all these processes.

In this context, a service-providing company, whose service is the creation of industrial cleaning solutions, produces Recyclable Raw Material (RRM) through the processing of waste collected during the cleaning activities of the company, located in the state of Minas Gerais, which is object of this study. The RRM is returned to this industry to be reintegrated into the production chain of liquid pig iron, which characterizes the process as being of a Reverse Logistics nature. Aiming at achieving greater knowledge on the subject, the research questions of this work were: How is the formation process of RRM? What are its benefits? Are there any limitations on its use?

This research aimed to: conduct a study on the formation process of recyclable raw material (RRM), pointing out benefits and limitations of its reuse in the process of manufacturing liquid pig iron; describe the manufacturing process of pig iron; and conduct a survey of major Brazilian steel companies regarding waste generation and recovery rates.

In the development of this work, the main authors consulted were: [2-5].

\section{THEORETICAL FRAMEWORK}

\section{1 THE STEEL INDUSTRY}

The $20^{\text {th }}$ century was marked by the advent of a large metal-mechanical complex around the world. Along with oil and electricity, steel was one of the pillars of this complex that has profoundly transformed mankind's lifestyle [6].

The Brazilian iron and steel production sector in the early 20th century had little significance. From 1910 onwards, the sector gained notoriety in the existing debates, drawing attention to the need for investment [7].

Investments began in the state of Minas Gerais, gaining strength with the creation of Companhia Siderúrgica Nacional in 1941. Afterwards, the government created decrees in order to favor and stimulate the sector. With these investments, national production went from 3000,00 tons per year in mid-1901 to $500.000,00$ tons per year from mid-1915 onwards [7].

Between 1917 and 1930, 14 new companies were created in the sector, in addition to a pre-existing one. Three companies are noteworthy: Companhia Siderúrgica Belgo-Mineira, founded in 1921, Companhia Brasileira de Mineração e Metalurgia, created by Cia. Mecânica e Importadora, in 1925, and Cia. Brasileira de Usinas Metalúrgicas, created by Hime \& Cia, in 1926. These three companies not only quickly dominated the sector, but also diversified the domestic production structure, introducing themselves more sharply into the production of steel and rolled steel [7].

The steel industry's post-war growth was overwhelming, with an average annual increase rate in steel production of $5 \%$, from 1945 to 1979 . After a period of stagnation in the 1980s, the steel industry began a restructuring phase, marked by a substantial increase in production, greater pursuit of technological innovations in processes and products, greater shareholder concentration and fewer workers [5].

According to [5], this type of industry has been undergoing major changes, from its structure to the way steel is produced. Nowadays, these transformations have been happening at a faster rate, since there are forces that influence the steel companies, such as the following:

\section{- Capital costs}

Comparing manufacturing costs and value added to the raw material, there is a very high start-up capital requirement, especially for large industries that utilize coke plants, sintering and/or pelletizing, blast furnaces and steel mills. There is, therefore, a tendency to reduce their implementation costs in order to reduce the final price of the product from the very beginning of the production chain, avoiding loss of quality but also maintaining a competitive product [8].

\section{- Limited raw material supply}

The basics for producing steel are iron ore, especially hematite and mineral coal, both of which are not found pure in nature, their processing being thus necessary for their use. Lately, processes have been making use of scrap originated from waste, waste of sinter fines, ore fines, among others, in order to complete the metallic load for iron and steel production and to fulfill the low supply [9].

Although there is a large amount of iron ore available in the world, deposits are concentrated in a small portion of countries. There are still limitations regarding the maximum possible amount of reuse of the waste from scrap and fines, due to the risk of steel contamination and loss of quality in the case of special steels [5].

\section{- Environmental Requirements}

The steel companies that use charcoal in their processes and those that use mineral coal coke, the latter less expressively, are the main focus of environmental agencies, especially due to the solid waste they generate. In recent times, there has been an effort to advance and update environmental legislation to match international requirements and technological advances, especially with regard to licensing and license renewal. The COPAM Normative Deliberation Number 49/2001 was created, bringing new requirements for dedusting systems, in the stages of handling and sifting of raw materials and regularization regarding the licensing of steel mills [10].

The steel industry is a major consumer of energy and materials, as well as being responsible for considerable pollutant emissions, both in the form of liquid effluents and solid waste. During the last decades, the steel industry has improved its energetic efficiency, increased productivity and decreased pollutant emissions. An important peculiarity is the production of energetic byproducts and inputs that can be used in the plant itself or in other economic sectors [5].

The creation of COPAM Normative Deliberation Number 49/2001 was a milestone for the sector in the state of Minas Gerais, as it brought innovative requirements for the implementation of dedusting systems in the stages of reception, handling and sifting of raw materials and regularization regarding environmental licensing of companies. It also demonstrates an effort to seek measures to control coal consumption, such as the creation of 
planted forests and the restriction of the exploitation of native forests, encouraging sustainable management. Coal accounts for about $70 \%$ of the final product cost and is essential to the production process of pig iron [10].

\section{- New materials}

This is one of the biggest motivators for the transformations that occur in the steel industry, and the factor that encourages them; not only does it encourage their production, but also the use of new raw materials. With advances in the reuse of sintering fines to complete the metallic load in pig iron production, the use of iron ore is reduced. Rolled steel, when it becomes scrap metal, is a type of waste that can be introduced back into the feeding process of the converting furnace, in the steel mill, in the production of liquid steel [5].

This subject is commonly not often discussed due to the companies' information protection processes and market secrets. What is generally seen is the use of steel waste in other areas, as described by [11], where the use of steel scale as an aggregate of concrete instead of sand was investigated in order to reduce the use of sand (a natural resource); but the authors also stress that it is necessary to carefully observe the resistance offered by this concrete, due to oil and grease contamination originating from the scale production process.

\section{2 ENVIRONMENTAL SUSTAINABILITY}

According to [12], "sustainable" means something that is enduring, lasts for many years and can be conserved, and can thus impart the idea of continuity. Following this line of thought, companies are faced with the need to create new processes and reevaluate the relationship between economy, society and nature in order to achieve sustainability.

During Agenda 21, it was agreed that development and conservation must always go hand in hand, thus undermining the idea that, during the process of evolution, it is not possible to both preserve and economically develop, especially in underdeveloped countries [13].

Saving natural resources and reusing waste are the main tools for sustainable development and for the maintenance of life on the planet and of survival resources for the next generations [13].

Since sustainable development aims to meet the needs of current and future generations, it is up to the current generation to ensure that these needs are met, as future generations cannot yet act [14].

The term "sustainability" has two origins: one is based on ecology, in what concerns resilience due to the misuse of available natural resources by man, or due to natural events such as earthquakes, tsunamis, etc. A second origin is of economic nature, which arose through the perception of the finitude of natural resources in the purpose of production, since, with technological advance, the possibility of shortage of raw materials was recognized [15].

The concept of sustainability grew from the environmental crisis of 1950, due to the several occurrences of environmental disasters, and has been gaining traction due to its wide dissemination in the media [16].

Some of sustainability's biggest enemies are social inequality and misinformation, which still lie at the root of the lack of interest in the topic. As a result, the defense of the third dimension of sustainability grows: this is of a social nature, calling for a sustainable society which offers the minimum necessary for a dignified life to its citizens and in which no one consumes goods, or natural and energy resources that are harmful to others. Its aim and challenges being the eradication of poverty and the definition of the acceptable inequality standard, the social dimension seeks to define minimum and maximum limits of access to material goods and to implement the very desirable social justice [15].

The concept of sustainability is related to Darwin's research, which considers the trajectory of birth, development and death of species. Species follow one another, some disappear and some arise. It was like this with our hominid ancestors, and understanding what was the extinction factor of these species makes us identify ways to prevent the extinction of mankind and even to predict environmental events that could cause its disappearance [15].

\section{3 SOLID WASTE}

Issues related to solid waste have been widely explored in scientific studies, as they are one of the biggest difficulties faced by a society that seeks sustainability [1].

There are several types of solid waste, among them industrial waste. It results from industrial activities and is found in solid, semi-solid, gaseous (when contained), and liquid states. Its particularities make it impossible for it to be released into the public sewage system or into bodies of water, or require technical or economically unfeasible solutions given the best available technology. Included in this definition is the sludge from water treatment systems and those generated from pollution control equipment and installations [1].

The steel industry is responsible for generating solid waste in great variety and quantity, its recycling and reuse being therefore critical. With the growing concern about environmental issues, several industries began to invest in new alternatives to solve the problems arising from the generation and disposal of waste [2].

The most important steel waste is classified into slag, dust and sludge from blast furnaces or steel mills, scale and coal and ore fines. The steel industry produced 13.5 million tonnes of waste, with an average of $435 \mathrm{~kg} / \mathrm{t}$ of steel produced. Revenue generation through the recycling of these materials has made companies act in a new way on the issue of environmental management [2].

Industrial waste has attracted great interest and gained importance in the environmental scenario, in industry, economy and in the academic community, since it is generated by various types of production processes, resulting in huge quantities in Brazil and worldwide [17].

It is important to remark that every industrial enterprise generates waste and uses inputs in all its processes. Entrepreneurs often associate the taking of environmental preservation actions with additional expenses. Consequently, possibilities of cost reduction are not taken into account. Actions aimed at environment protection can bring profit, or at least neutralize the expenses related to saving energy sources and/or other natural resources [18].

In order to ensure the well-being of the population, it is necessary that companies strive to provide and maintain healthy working conditions such as safety, training and leisure for their employees and their families, as well as limiting or eliminating the levels of production and/or emission of toxic waste arising from its production process and the use or consumption of its products, ensuring the neutralization or maximum reduction of environmental damage in general and ensuring the preparation and delivery of products or services in accordance with the quality and safety conditions desired by consumers [18]. 


\section{4 REVERSE LOGISTICS}

Reverse logistics enables saving some resources in the company's production process, since waste generated will be reused, reducing the consumption of raw materials and other resources [1].

The National Policy on Solid Waste classifies reverse logistics as an instrument of economic and social development characterized by a set of actions, procedures and means designed to enable the collection and return of solid waste to the business sector for reuse in its own or in other production cycles, or other environmentally appropriate final destination [1].

From a perspective of business logistics, considers that "the term refers to the role of logistics in product return, reduction in the source, recycling, material replacement, material reuse, waste disposal, refurbishment, repair and remanufacturing" [19].

Reverse logistics is a reality in many industrial processes nowadays; the need for further study on the subject continuously increases, following a gradual increase of the need to reintroduce waste into the production chain in order to save natural resources [20].

According to the National Policy on Solid Waste [1], reverse logistics has many advantages, such as preventing waste from polluting or contaminating the environment. It also allows savings in production processes and the use of cleaner technologies, among others. [1].

According to [20], there are examples that show that this practice has been used for years. However, due to some factors it has been noticed that, in recent years, there has been a considerable increase in this type of thought and activities related to recycling and reuse. These factors include environmental concerns, competition and cost cutting.

The environmental factor is important because there is a tendency for environmental legislation to make the company increasingly more obligated to take responsibility for the entire life cycle of its products. This means it has a responsibility after delivery to its customers as well, and also for the possible impacts that may be generated in this process [20].

Other factors are cost reduction and the company's image to customers, aiming to show that the company is active in social and environmental issues, since it would be making use of clean technologies, reducing waste, recycling and reusing products that would certainly be otherwise discarded [21].

This can lead to differentiation in relation to competitors, since retailers see an advantage because they believe that there is an appreciation of companies that have a more liberal return policy [20], as highlighted by [22], [3] and [3]. Interviewed a number of companies and demonstrated that low investment in reverse logistics generates substantial savings. He quotes a Sears executive who said, "Reverse Logistics is the ultimate frontier in cost savings" [23].

According to [3] reverse logistics is the process of planning, implementation and control of the flow of post-consumer and after-sales products and their flow of information from the point of consumption to the point of origin, in order to recover value or perform proper disposal. This concept contributes to the consolidation of the concept of sustainability in the business sphere, supported by the concepts of environmental and economic development.

From [3] propose that a proper design of reverse logistics systems (when there is post-consumer product flow back to manufacturers and suppliers) can be used not only to comply with legislations regarding product recall and sustainability, but also as a source of competitive advantage. For example, remanufactured products represent a significant addition to some companies' product lines, enabling them to serve otherwise unattainable consumer segments. Everyone benefits from this: companies, consumers and the environment.

For a reverse logistics strategy to work, action must be started at the end of the chain, that is, with the end consumer. The whole process follows a flow with basic steps, which can be represented in a cycle diagram, in which the lifespan of the given product ends and it becomes waste. Waste is collected and separated according to its classification in the recycling process so that it can be used as raw material in the production of a new product, which in turn will be destined for trade through distribution and sales lines [24] (Figure 1).

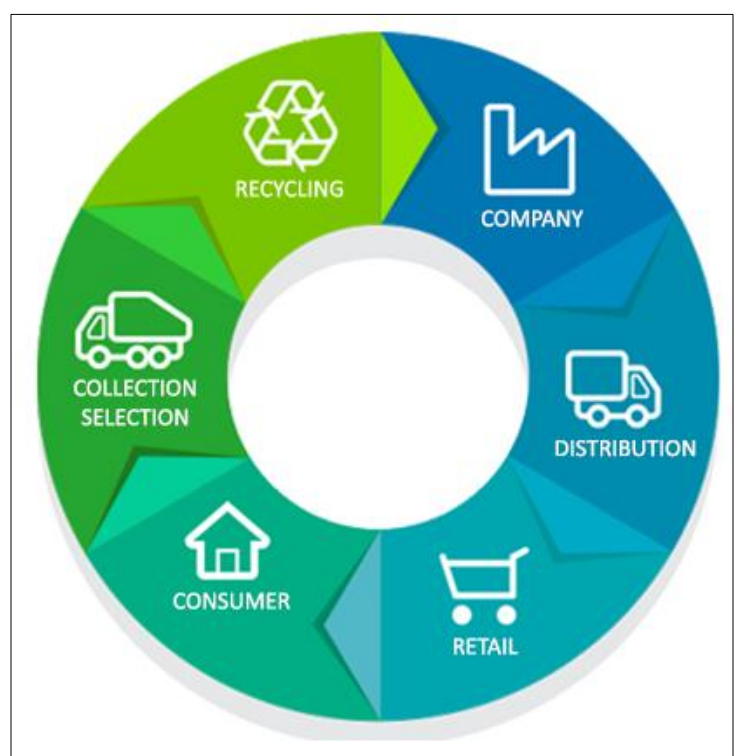

Figure 1: Simplified reverse logistics flowchart. Source: Adapted from [24].

The biggest problem faced is the lack of systems capable of integrating Reverse Logistics with the common logistics flow, which causes these services to be outsourced or performed by their own systems [22].

Waste sorting is a major partner of reverse logistics, as waste is separated by class and recycling or reuse potential. The separation of waste and waste sorting prevents solid waste from being sent to a landfill, reducing transportation costs and extending the landfill's lifespan. Waste sorting also contributes to the creation of jobs in society through waste pickers' associations. These associations, in addition to generating jobs, offer an option to many people that otherwise only have marginalization as a choice. They discover in recycling a new life, and a new purpose for waste [25].

\section{5 RECYCLABLE RAW MATERIAL (RRM)}

Recycled Raw Material is part of the fundamental concept of reverse logistics, which is the return of waste generated during the production process to the beginning of the production chain, preferably in the same process in which it was generated [1].

In the production process of pig iron in a company, the blast furnace's metallic load is composed of sinter (produced in sintering), iron ore and recyclable raw material (RRM). For the steel industry, the use of sinter is of great importance, as it can be used in place of iron ore, and because it is produced on the plant itself, it is cheaper [27].

RRM is composed of all usable waste material generated throughout the steelmaking process, such as sinter fines, which are 
generated throughout the sinter-making process. They can also originate from the fall of materials during transportation on conveyor belts, from cleaning residues on equipment and residues of raw materials used in the manufacture of sinter. Dust from dedusting systems (which is collected by the system itself and deposited in collection boxes where it will be transported). Grinder swarf (generated during the thinning of the billet in the rolling process). Blast furnace cyclone powder (generated during blast furnace gas washing in the gas scrubber). Ore fines (originated from falls during transport on conveyor belts, cleaning residues on equipment) [28].

\section{METHOLOLOGY}

Regarding the objectives, this research was characterized as exploratory and explanatory. In exploratory research, critical points are verified, initial contacts for field entry are established and the necessary data sources for the study are located [29]. In regard to explanatory research, fact records are generated, analyzed and interpreted, their causes being then identified [30]. The research was also characterized as quali-quantitative [30].

As for the technical procedures, research was conducted through both bibliographic and field studies. The literature research consisted of data collection in databases pre-defined before the study [31]. The data were researched in scientific articles, doctoral dissertations, master's theses and journals through the Google Scholar and SciELO platforms, with the keywords: waste generation, steel industry, waste reuse in the steel industry, sustainability in the steel industry, advantages of reverse logistics, impacts caused by landfills, among others, totaling about 50 researched works. Some data were obtained from employees of the company under scrutiny, since literature on the subject is scarce.

The survey on the generation of waste and its recovery rates was obtained through research of the main Brazilian steelmakers [32]. The research on the process of pig iron formation was carried out by consulting the works of Silva [27] and UFSC [33].

Field research was also conducted in order to comprehend the process of formation of Recyclable Raw Material (RRM), as well as the benefits and limitations of its reuse [34]. To this purpose, five visits were made to the company that provides services to the steel company in study. Data were collected from the month of January 2018 to October 2018. The service provider company is responsible for collecting waste from the steel company, for its recycling, for forming the RRM and returning the RRM to the steel company from Minas Gerais.

\section{RESULTS AND DISCUSSION}

Pig iron, the main raw material for steelmaking, is a $95 \%$ ferrous liquid obtained through the purification of iron ore by heating. This process is carried out in the metallurgical reactor, which is called the blast furnace [35].

However, thin materials cannot be used in this process, as they are carried by the rising gases. To prevent this, the ore undergoes an agglomeration process. The iron ore agglomeration processes most commonly used as blast furnace fillers in the steel industry are pelletizing and sintering.

Pelletizing produces the agglomerate called pellet and the process is carried out in the mining companies themselves. The agglomeration process involves physicochemical steps in order to aggregate the portion of ore fines (size inferior to $0,15 \mathrm{~mm}$ ) into spheres with the appropriate particle size and quality. In order to produce sinter, a process of agglomeration of the basic raw materials is required, which is called sintering: that is, the heating of the basic raw materials below the melting point, from the burning of solid fuel (coke) agglomerated to iron ore and fluxes, the outcome being the sinter produced by the steel mills themselves [36].

In the pig iron production process, the blast furnace's metallic load is formed from sinter (produced in sintering), iron ore and recyclable raw material (RRM). Percentages were not disclosed by the company which is the subject of this research, due to internal information security policies. The use of sinter is of great importance because it can be used in place of iron ore, and because it is produced on the plant itself it is less expensive [27].

For the production of pig iron (Figure 2) it is necessary to transport the metallic load through conveyor belts that feed the blast furnace. In addition, fluxes and atmospheric air are inserted, and the iron ore, which composes the metallic load, is reduced by carbon until pig iron is obtained. This whole process occurs at an approximate temperature of $1000^{\circ} \mathrm{C}$ [33].

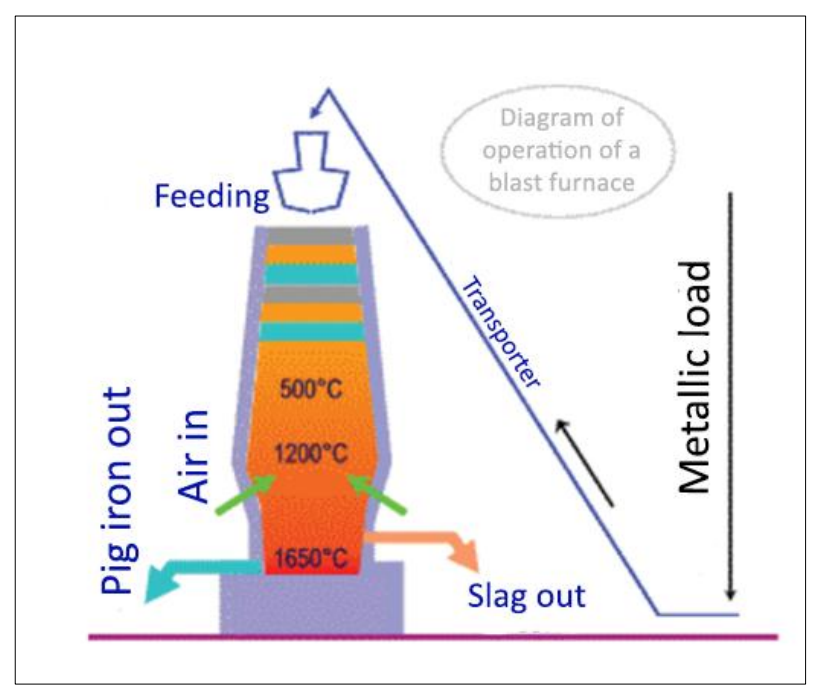

Figure 2: Pig iron production flow chart. Source: Adapted from [33].

Steel industries are major producers of solid waste. In 2006, the main Brazilian steel mills produced about 13 million tons of waste, as shown in Table 1. Generation varies considerably across companies, depending on factors such as technological process, raw material, energy source, etc. [32].

Table 1: Generation and recovery of solid waste from the main steel companies in Brazil (2006).

\begin{tabular}{|c|c|c|}
\hline Companies & $\begin{array}{c}\text { Waste } \\
\text { generation }^{(\mathbf{1})}\end{array}$ & $\begin{array}{c}\text { Recovery } \\
\text { rate }^{(\mathbf{2})}\end{array}$ \\
\hline IBS $^{(3)}$ & 0,42 & $98 \%$ \\
\hline ArcelorMittal (long steel) & N/A & $92 \%$ \\
\hline ArcelorMittal (flat steel) & N/A & $58 \%$ \\
\hline CSN & 0,66 & $99 \%$ \\
\hline Gerdau & N/A & $77 \%$ \\
\hline Usiminas (Cubatão) & 0,77 & $97 \%$ \\
\hline Usiminas (Ipatinga) & 0,73 & $94 \%$ \\
\hline V\&M & 0,31 & N/A \\
\hline Vilares & N/A & N/A \\
\hline
\end{tabular}

Source: Adapted from [32].

Overall, solid waste recovery rates in most companies were above $90 \%$ (Table 1). These numbers are only reached through widespread acceptance of steel aggregates by other industrial sectors. Among these residues a variety of metals can be 
reused, such as aluminum, antimony, cadmium, chromium, tin, manganese, molybdenum, selenium, thallium and vanadium, representing $78 \%$ of the waste generated [27].

The ease of commercializing waste (and even its resulting revenue) apparently diminished preventive actions, since the generation rate between 2004 and 2006 increased by $22 \%$ from 0,268 tonnes/tonne of crude steel to 0,327 tonnes/tonne of crude steel [32].

In 2013, Brazilian steelmakers produced 17.7 million tonnes of waste, of which three million were scrap with potential for reuse by the sector itself. Waste production per ton of steel reached $0,594 \mathrm{t}$ [37].

In Minas Gerais, from 2009 to 2018, the average amount of solid waste declared by the steel industry in the Inventário de Resíduos Sólidos (Solid Waste Inventory) was 13.154.468,00 tonnes [46], being one of the sectors that generate the largest amount of solid waste in the state of Minas Gerais.

The most important types of waste from steelmaking are blast furnace slag (mainly marketed to cement companies) and steel slag (used in road building). The other residues in the steel sector are dusts, sludge, fines and scale [32].

A steel company from the state of Minas Gerais found the possibility of inserting the waste generated into its own production processes through the creation of Recyclable Raw Material (RRM), which is composed of usable waste generated throughout the steel production process, such as sinter fines, dust from dedusting systems, grinder swarf, high cyclone dust and ore fines [28]. Inserting generated waste into the production process itself is a great option to send it to a correct final destination, to reduce the use of raw materials and, consequently, to reduce costs. In order to be introduced, waste sometimes needs beneficiation, which may be of a simpler nature, such as a process of sifting, or more complex, involving physicochemical steps. The simpler the beneficiation process is, the better, since it involves less skilled labor and less technology.

The waste generated throughout the company's production process is collected daily by the service provider. All of it is transported in trucks from the provider itself and taken to the beneficiation plant (Figure 3). Upon arrival at the plant, they are separated according to their specifications. Subsequently, they are placed in labelled stalls (Figure 4) [28].

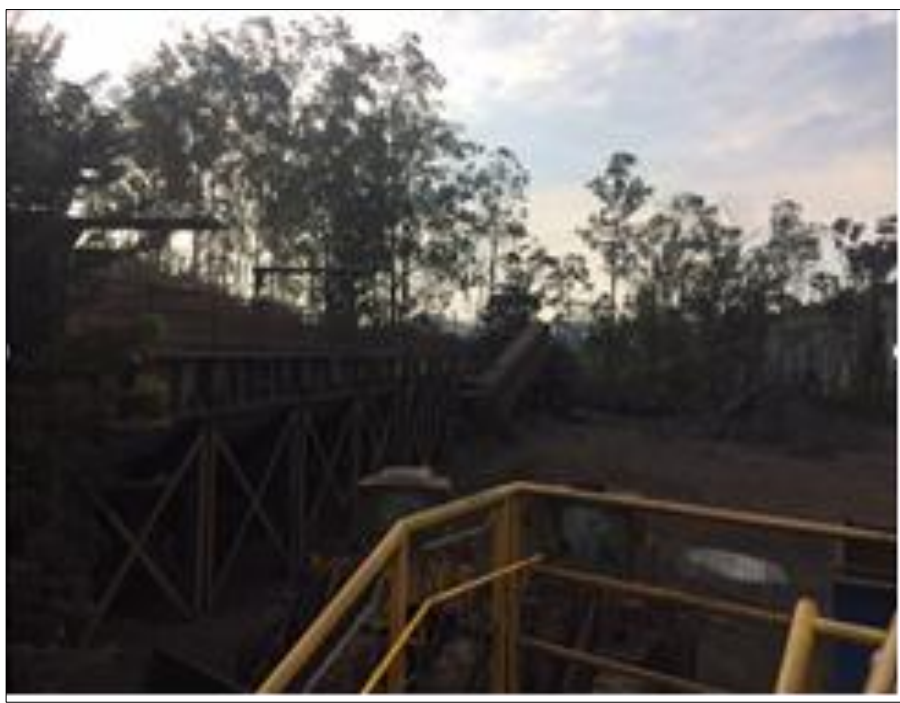

Figure 3: Partial view of the beneficiation plant (silos, conveyor belt, and homogenized material).

Source: [28]

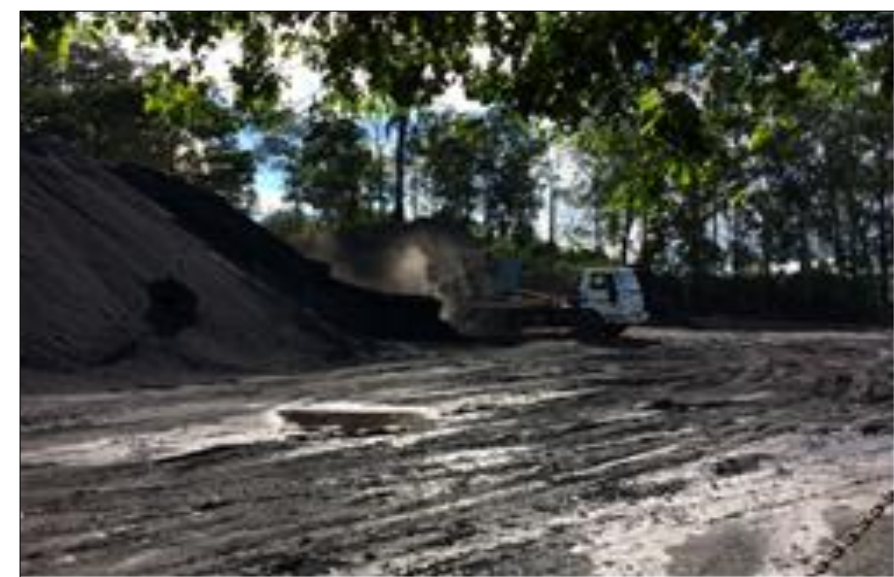

Figure 4: A truck unloading sintering fines onto a stall.

Source: [28].

From the stalls the materials are directed by a wheel loader (Figure 5) to sieves in order to remove coarse solids that may damage equipment or contaminate the RRM. Subsequently, they are packed in identified silos (Figure 6). The silos are regulated to adjust the dosage of materials according to the specifications of the company under study. From the silo, they are sent to conveyor belts that homogenize the materials forming the RRM (Figure 7), which is transported (through bucket trucks) to the raw material yard, located in the sintering area. Deliveries are made at the request of the company itself [28].

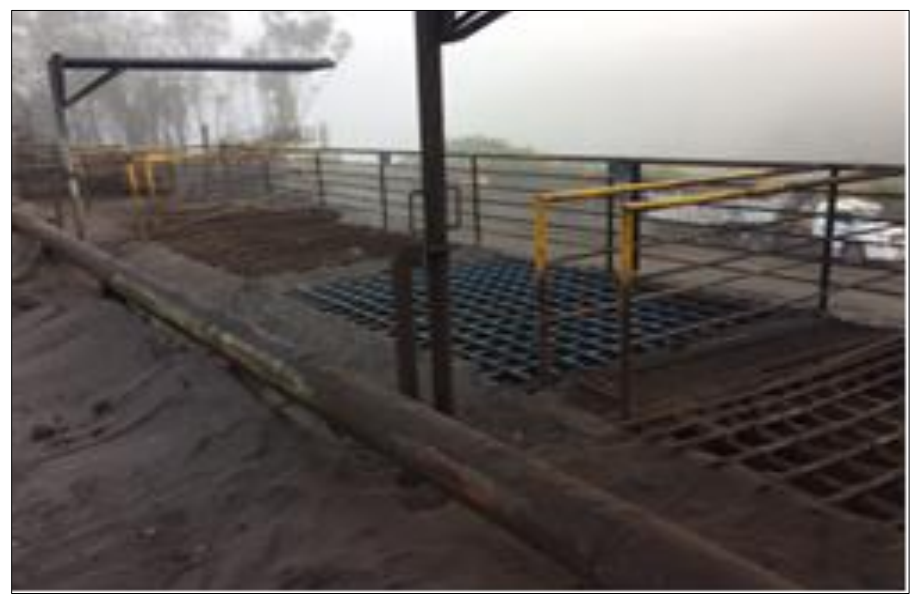

Figure 5: Silo sieves. Source: [28]

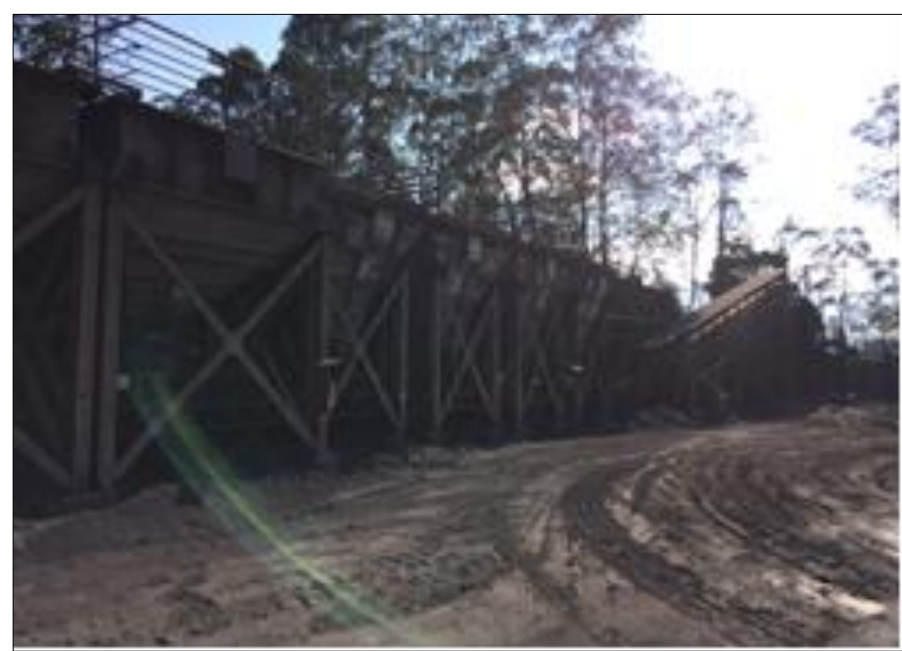

Figure 6: Dosing silos.

Source: [28]. 


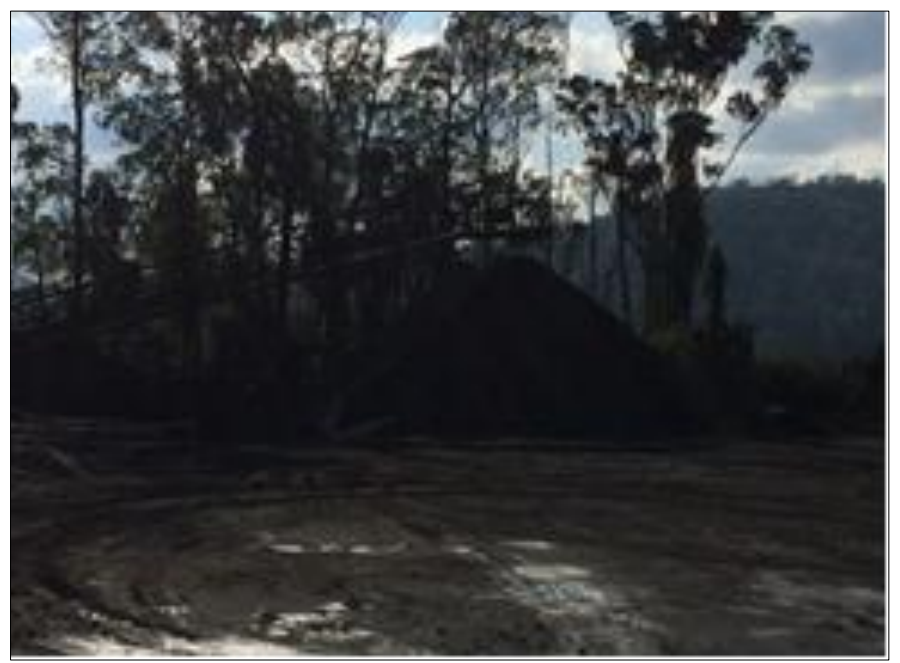

Figure 7: Homogenized material. Source: [28].

RRM has a production revenue of 50 tonnes (Table 2), following industry standards, in order to prevent contamination of the pig iron.

Table 2: RRM revenue.

\begin{tabular}{|c|c|c|}
\hline Raw materials & $\begin{array}{c}\text { Weight } \\
\text { (tonnes) }\end{array}$ & $\begin{array}{c}\text { Silo } \\
\text { identification } \\
\text { number }\end{array}$ \\
\hline Sintering fines & 20 & 4 \\
\hline Dust from dedusting systems & 1 & 4 \\
\hline Grinder swarf & 4 & 1 \\
\hline Blast furnace cyclone dust & 20 & 2 \\
\hline Iron ore fines & 5 & 3 \\
\hline Total & 50 & \\
\hline
\end{tabular}

Source: Adapted from [28].
The data presented in Table 3 show the average price per tonne of iron ore in 2018, considering the months of January and June (weekly average and monthly average). Taking into account the average price per tonne of iron ore in June 2018 (the time the survey was conducted) and the price of the dollar quoted at the same time, which was $\mathrm{R} \$ 3,8552$ [45], the price, in Brazilian Reais, of the ton of iron ore corresponded to $\mathrm{R} \$ 293,11$.

Table 3: Average price of iron ore in 2018.

\begin{tabular}{|c|c|c|c|}
\hline Market rate & $\begin{array}{c}\text { 30 January } \\
\mathbf{2 0 1 8}\end{array}$ & $\begin{array}{c}\text { Weekly } \\
\text { average (last } \\
\text { 5 days)/June }\end{array}$ & $\begin{array}{c}\text { Monthly } \\
\text { average/June }\end{array}$ \\
\hline & US\$/dmt & US\$/dmt & US\$/dmt \\
\hline $\begin{array}{c}\text { Metal } \\
\text { Bulletin }\end{array}$ & 72,997 & 74,25 & 76,03 \\
\hline
\end{tabular}

Source: Adapted from [38].

Figure 8 shows a large variation in the price of iron ore between July 2010 and January 2018. This commodity peaked at US $\$ 190$ at the beginning of 2011 and descended to less than US $\$ 40$ at the end of the fourth quarter of 2015. There was, therefore, a downward trend in the price of iron ore during the analyzed series, which started the period at US\$130 and closed near US\$70.

Iron ore suffers from year-round price fluctuations due to various factors such as fluctuations in the dollar quotation, the available amount in suppliers' stocks and buyers' stocks, ore purity and trade restriction or facilitation between certain countries or economic blocks, to the detriment of political positions. As with every commodity, the supply-demand law influences price so that an increase in consumption, without available supply, can cause a price increase. Large importers, especially in times of virtuous cycles in their economies, tend to increase their import rates to meet the necessary investments, which can cause significant price variation.

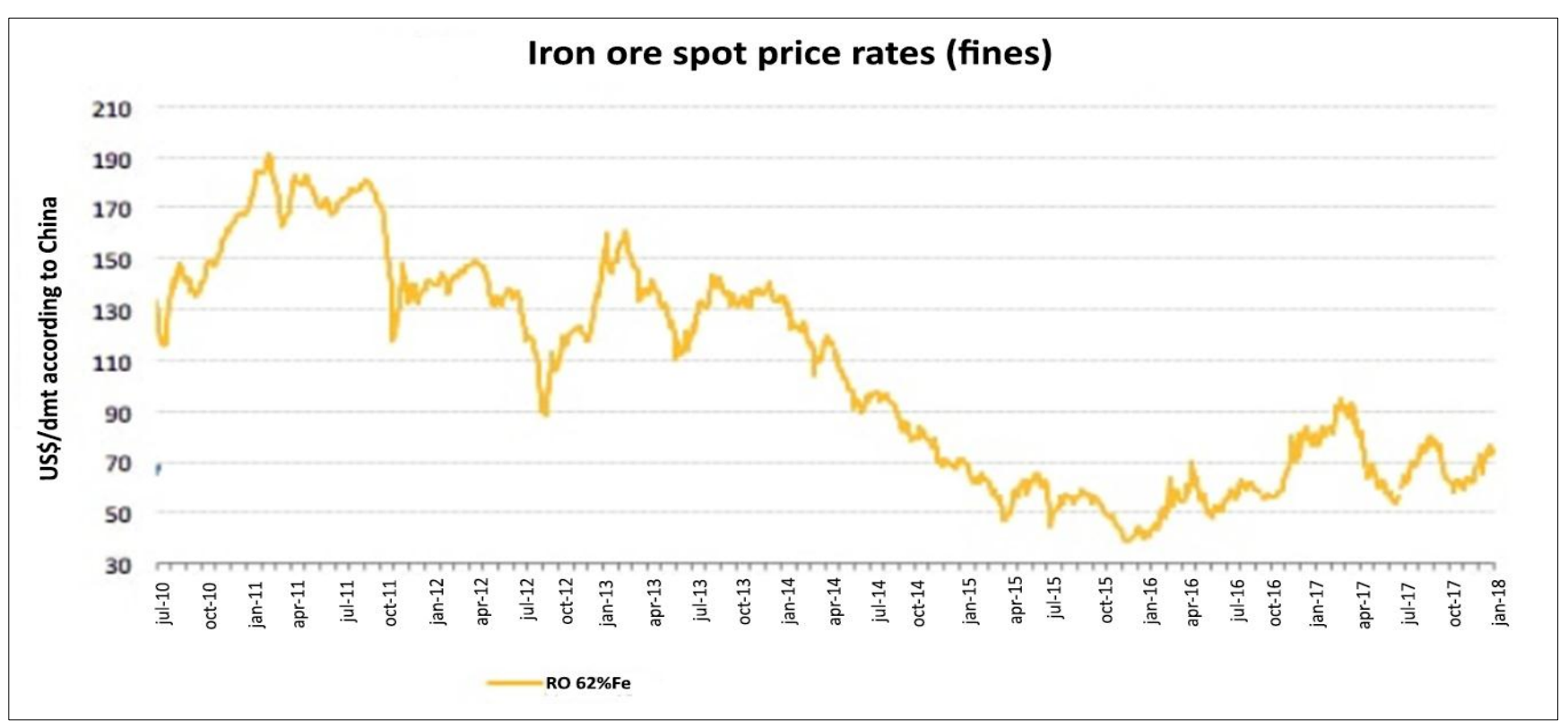

Figure 8: Variation in iron ore prices between 2010 and 2018. RO 62\%Fe - Raw Ore, 62\% iron. Source: Adapted from [38].

The service provider delivers around 100 tonnes/day of RRM to the company under study, totaling 3,000 tonnes per month. The tonne of RRM cost, in 2018, R\$ 38,90 [28] and the tonne of iron ore cost $R \$ 293,11$. In light of this data it was possible to identify an economy for the company of $86,80 \%$, comparing the costs with the acquisition of iron ore (3,000 tons) and the RRM
(3,000 tons) (Table 4). These data show the great importance of using RRM, since, in addition to economic gains, the use and need for iron ore extraction, as well as the disposal of waste in the environment, are reduced, considering that they are incorporated back into the industry's production chain. 
Table 4: Comparison of prices between RRM and iron ore.

\begin{tabular}{|c|c|c|c|}
\hline & $\begin{array}{c}\text { Amount in } \\
\text { tonnes/mounth }\end{array}$ & $\begin{array}{c}\text { Cost by } \\
\text { tonne/in } \\
\text { Brazilian Reais }\end{array}$ & $\begin{array}{c}\text { Total costs } \\
\text { in Brazilian } \\
\text { Reais/month }\end{array}$ \\
\hline Raw material \\
\hline RRM & $3.000,00$ & 38,90 & $116.700,00$ \\
\hline Iron ore & $3.000,00$ & 294,77 & $884.310,00$ \\
\hline & \multicolumn{3}{|c|}{ Savings } \\
\hline
\end{tabular}

Source: Adapted from [38].

It is important to consider that iron ore extraction causes negative impacts on the environment. Exploited areas lose their resilience, that is, their ability to regenerate without human interference [39], since it causes loss of soil fertility and loss of seed bank. Thus, it takes a great amount of time and resources to recover these areas.

In the work of [40], an important consideration is made about the recovery of mined areas, which collaborate with the use of RRM. The author emphasizes the impossibility of returning the mined area to a situation similar to the original one (restoration in the broad sense). For these areas, rehabilitation is recommended; that is, it may have other purposes other than precisely the formation of a forest [39].

With the use of RRM 3,000 tonnes of waste are removed monthly from the environment. [40] demonstrate in their work the difficulty of finding suitable areas for construction of landfills, the distance traveled until waste reaches the landfill increasing over the years. This problem is mainly experienced in metropolitan regions due to the existence of environmentally protected areas and the impacts caused to the surroundings [41]. In addition, through the use of RRM it is possible to avoid impacts such as changes in Biological Oxygen Demand (BOD) and Chemical Oxygen Demand (COD), pollution of water resources, production of pollutant gases and particulate materials and degradation of large extensions of soil due to contamination with substances such as heavy metals and toxic organic materials. In what concerns social issues, the poor conditions of waste pickers are minimized and disease vectors are reduced [42].

In general, the impacts mentioned were listed on the checklist proposed by [42] (Table 5).

Table 5: Classification of impacts listed on the check-list.

\begin{tabular}{|c|c|c|c|c|}
\hline Columns1 & Columns2 & Columns3 & Columns4 & Columns5 \\
\hline Class & $\begin{array}{c}\text { Kind } \\
\text { (P: Positive } \\
\text { and N: } \\
\text { Negative) }\end{array}$ & $\begin{array}{l}\text { Magnitude } \\
\text { (S: Strong, M: } \\
\text { Medium and } \\
\text { W: Weak) }\end{array}$ & $\begin{array}{c}\text { Scope } \\
\text { (L: Local and } \\
\text { R: Regional) }\end{array}$ & $\begin{array}{c}\text { Frequency } \\
\text { (T: } \\
\text { Temporary } \\
\text { and I: } \\
\text { Intermittent) }\end{array}$ \\
\hline \multicolumn{5}{|l|}{ Impacts } \\
\hline $\begin{array}{l}\text { Alteration of } \\
\text { surface water } \\
\text { resources }\end{array}$ & $\mathrm{N}$ & $\mathrm{S}$ & $\mathrm{R}$ & $\mathrm{C}$ \\
\hline $\begin{array}{c}\text { Alteration of } \\
\text { underground } \\
\text { water resources }\end{array}$ & $\mathrm{N}$ & $\mathrm{S}$ & $\mathrm{R}$ & C \\
\hline $\begin{array}{c}\text { Alteration of } \\
\text { soil quality }\end{array}$ & $\mathrm{N}$ & $S$ & $\mathrm{~L}$ & $\mathrm{C}$ \\
\hline $\begin{array}{c}\text { Alteration of air } \\
\text { quality }\end{array}$ & $\mathrm{N}$ & M & $\mathrm{R}$ & C \\
\hline $\begin{array}{c}\text { Impacts on } \\
\text { human health }\end{array}$ & $\mathrm{N}$ & $\mathrm{S}$ & $\mathrm{R}$ & $\mathrm{C}$ \\
\hline
\end{tabular}

Source: Adapted from [42].

In addition to the factors described, [43] considers that the use of RRM reduces noise pollution caused by ore mining, as well as land use conflicts, depreciation of surrounding properties and urban traffic disturbances.
In order to combine mining with sustainable development, one of the steps is the implementation of operations of recycling and reuse of the minerals themselves, as well as of inputs [44].

Thus, RRM generates savings for the industry, while simultaneously collaborating with the preservation of the environment, avoiding impacts and externalities, contributing to the sustainable development of the sector.

However, its use is limited, as its processing does not guarantee that, when used in high proportions, there will be no alteration in the final quality of pig iron and the integrity of equipment such as the blast furnace [5]. Also highlighted as limitation is the loss of quality in the case of special steels and risk of steel contamination.

There is a lack of studies on waste reuse in the steel production chain. From a total of 92 studies, carried out between 1962 and 2015, on the reuse of waste generated in the Brazilian steel industry, dusts were the only class that presented incorporation of waste in the steel production cycle itself, with only 1 work focused on this purpose [27].

\section{CONCLUSION}

The development of this study allowed an analysis of the use of RRM (Recyclable Raw Material) in the production of sinter in a steel company from the state of Minas Gerais, in order to reduce iron ore consumption in this process. Through analysis of RRM and iron ore costs, it was possible to understand the importance of sinter for the steelmaking process, since its use is much more economically advantageous than using purely iron ore. The use of RRM significantly reduces the iron ore load on the sinter, increasing the profit margin and meeting the basic principle of reverse logistics, which aims to return all the waste generated (or as much as possible) to the company's production process or to insert it into another process. Positive strengths related to the use of RRM include reduced mineral extraction and noise pollution, reduced water, soil and air pollution, as well as the generation of secondary problems such as land use conflicts, depreciation of properties surrounding mining areas and disturbances to urban traffic. Significant savings in sinter production were identified through the insertion of RRM. It is, however, necessary to regulate this insertion, because the process still has limitations due to the risk of contamination of the pig iron and the risk of increasing the wear rate in the equipment involved in the process. The process of formation of RRM is often not adequately discussed due to companies' protection of information and market secrets, and thus it is of importance that this topic is explored in the academic sphere, as few works have been found. Partnerships between companies and universities should be encouraged in order to create cleaner technologies that reduce the impact of this activity on the environment, as well as to share the positive experiences of the steel industry, so that other industries can make use of reverse logistics.

\section{REFERENCES}

[1] BRASIL. Lei n. 12.305/10, de 18 de maio de 2012. Política Nacional de Resíduos Sólidos. PNRS. 2. ed. Brasilia, p. 10-12, maio. 2012. Disponível em: <https://fld.com.br/catadores/pdf/politica_residuos_solidos.pdf > Acesso em: 24 maio 2018.

[2] Da Cunha, Adriano Ferreira et al. Caracterização, beneficiamento e reciclagem de carepas geradas em processos siderúrgicos. Escola de Minas, Ouro Perto, v. 59, n. 1, p. sem paginação, jan. 2005. Disponível em: 
<http://www.scielo.br/scielo.php?pid=S0370-

$44672006000100014 \&$ script=sci_arttext $>$. Acesso em: 31 maio 2018.

[3] Guarnieri, P.; Corrèa, H. L.; Xavier, L. H. Logística Reversa e Sustentabilidade. Disponível em:

$<$ http://patriciaguarnieri.blogspot.com/2018/06/economia-

circular-e-logistica-reversa.html>. Acesso em: 13 nov. 2018.

[4] Leite, Paulo Roberto. Logística Reversa: Nova Área da Logística Empresarial. Revista Tecnologística, São Paulo, p. 102109, maio. 2002. Disponível em: <http://meusite.mackenzie.br/leitepr/LOG\%CDSTICA\%20REVE RSA\%20-

\%20NOVA\%20\%C1REA\%20DA\%20LOG\%CDSTICA\%20EM PRESARIAL.pdf $>$. Acesso em: 31 maio 2018.

[5] Da Costa, Márcio Macedo. Princípios de Ecologia Industrial Aplicado à Sustentabilidade Ambiental e aos Sistemas de Produção de Aço. 2002. 257 p. Tese (Doutor em Ciências em Planejamento Energético). Universidade Federal do Rio de Janeiro, COPPE, Rio de Janeiro, 2002. Disponível em: <http://www.ppe.ufrj.br/ppe/production/tesis/mmdacosta.pdf $>$. Acesso em: 09 maio 2018

[6] Burns, Edward McNall. A Revolução Industrial dos séculos. [S.l.: S.n.], [S.D.]. cap. 23 p. Disponível em: $<$ http://www.consciencia.org/a-revolucao-industrial-dos-seculosxix-e-xx>. Acesso em: 04 out. 2018.

[7] Barros, Gustavo. O Desenvolvimento do setor siderúrgico brasileiro entre 1900 e 1940: criação de empresas e evolução da capacidade produtiva. Revista de História Econômica e Economia Regional Aplicada (HEERA), Juiz de Fora: UFJF, v. 8, n. 14, janjun 2013. p. 9-32. Disponível em:<http://www.ufjf.br/heera/>. Acesso em: 25 maio 2018

[8] Ciclo Do Aço. 2013. Disponível em: <http://www.cerviflan.com.br/ciclo-do-aco.html>. Acesso em: 22 maio 2018.

[9] Santos, Jaqueline Guimarães. A Logística Reversa Como Ferramenta Para Sustentabilidade: Um Estudo Sobre a Importância das Cooperativas de Reciclagem na Gestão dos Resíduos Sólidos Urbanos. REUNA, Belo Horizonte, MG - Brasil, v. 17, n. 2, p. 81 96, jun. 2012. Disponível em: <http://revistas.una.br/index.php/reuna/article/viewFile/422/486>. Acesso em: 01 jun. 2018.

[10] Doval, Guilherme. Os Avanços das Exigências Ambientais na Siderurgia Mineira. Disponível em: $<$ https://www.ecodebate.com.br/2011/07/21/os-avancos-dasexigencias-ambientais-na-siderurgia-mineira-artigo-de-guilhermedoval/>. Acesso em: 03 maio 2018.

[11] Pereira, Fernanda Macedo; De Verney, José Carlos Krause; Lenz, Denise Maria. Metalurgia e Materiais: Avaliação do emprego de carepa de aço como agregado miúdo em concreto. REM: R. Esc. Minas, Ouro Perto, p. 463-469, out. 2011. Disponível

em:

<http://www.scielo.br/pdf/rem/v64n4/a11v64n4.pdf>. Acesso em: 24 maio 2018.

[12] Barreto, Nathalia Lima. O Principio do Desenvolvimento Sustentável. Caderno de Direitos, Piracicaba, v. 11, n. 20, p. 47-65, jun. 2011. Disponível em: <https://webcache.googleusercontent.com/search?q=cache:GoEP VrvsaKAJ:https://www.metodista.br/revistas/revistas- unimep/index.php/cd/article/download/187/501+\&cd=2\&hl=pt$\mathrm{BR} \& \mathrm{ct}=\mathrm{clnk} \& \mathrm{gl}=\mathrm{br}>$. Acesso em: 07 maio 2018.

[13] ONU. Assembleia Geral das Nações Unidas. Agenda 21. 1992. Disponível em $<$ http://www.mma.gov.br/estruturas/agenda21/_arquivos/consulta2 edicao.pdf $>$. Acesso em 18 maio 2018.

[14] Rocha, Juliana D.; Bursztyn, Maria Augusta. A Importância da Participação Social na Sustentabilidade do Desenvolvimento Local. INTERAÇÕES, [S.1.], v. 7, n. 11, p. 45-52, set. 2005. Disponível em: <http://file:///C:/Users/Igor/Downloads/496-10931-PB.pdf $>$. Acesso em: 18 abr. 2018.

[15] Do Nascimento, Elimar Pinheiro. Trajetória da Sustentabilidade: do ambiental ao social, do social ao econômico. Estudos Avançados, Brasilia, v. 26, n. 74, p. 51-64, out. 2011. Disponível em: <http://www.scielo.br/pdf/ea/v26n74/a05v26n74.pdf>.

[16] Quirino, Marcia Glebyane Maciel. Sustentabilidade em uma Conjuntura de Crise Ambiental: Noções Preliminares. [S.D]. Disponível em: <http://www.publicadireito.com.br/artigos/?cod=6cc17b31acdbbc cd>. Acesso em: 11 out. 2018.

[17] Moreira, J. M. S.; Manhães, J. P. V. T.; Holanda, J. N. F. Reaproveitamento de Resíduo de Rocha Ornamental Proveniente do Noroeste Fluminense em Cerâmica Vermelha. Cerâmica 51, Campos dos Goytacazes, p. 180-186, jan. 2005. Disponível em: <http://www.scielo.br/pdf/ce/v51n319/26789.pdf>. Acesso em: 02 jun. 2018.

[18] Kraemer, Maria Elisabeth Pereira. A Questão Ambiental e os Resíduos Industriais. Disponível em: <http://www.amda.org.br/imgs/up/Artigo_25.pdf>. Acesso em: 05 maio 2018

[19] Leite, Paulo Roberto. Logística Reversa: Nova Área da Logística Empresarial. Revista Tecnologística, São Paulo, p. 102109, maio. 2002. Disponível em: $<$ http://meusite.mackenzie.br/leitepr/LOG\%CDSTICA\%20REVE RSA\%20-

\%20NOVA\%20\%C1REA\%20DA\%20LOG\%CDSTICA\%20EM PRESARIAL.pdf>. Acesso em: 31 maio 2018.

[20] Lacerda, Leonardo. Logística Reversa: uma visão sobre os conceitos básicos e as práticas operacionais. Disponível em: <http://www.paulorodrigues.pro.br/arquivos/Logistica_Reversa_ LGC.pdf>. Acesso em: 05 jun. 2018.

[21] Junior, Sergio Silva Braga; MERLO, Edgard Monforte; NAGAN, Marcelo Seido. Um Estudo Comparativo das Práticas de Logística Reversa no Varejo de Médio Porte. Revista de Micro ePequena Empresa, Campo Limpo Paulista, v. 3, n. 1, p. 64-81, 2009 .

[22] Daher, Cecílio Elias; Silva, Edwin Pinto de La Sota; Fonseca, Adelaida Pallavicini. Logística Reversa: Oportunidade para Redução de Custos através do Gerenciamento da Cadeia Integrada de Valor. Red de Revistas Científicas de América Latina y el Caribe, Vitoria, ES, Brasil, v. 3, n. 1, p. 59-71, jan. 2006.

[23] Caldwell, Bruce. Reverse Logistics. Information Week. 12 de Abril de $1999 . \quad$ Disponível em: <www.informationweek.com/729/logistics.htm>. Acesso em 12 abr. 2018

[24]Blog Texaco, Logística reversa: o que é, como funciona e como aplicar. 2018. Disponível em: 
$<$ https://blog.texaco.com.br/ursa/logistica-reversa-o-que-e-comofunciona/>. Acesso em: 25 out. 2018

[25] Soares, Tamara Amaral; Rodrigues, Priscila Thais; Gonçalves, Gilmerson Inácio. A Importância da Logística Reversa no Âmbito Social, Ambiental e Econômico. Disponível em: <http://www.fatecguaratingueta.edu.br/fateclog/artigos/Artigo_58 .PDF>. Acesso em: 28 abr. 2018.

[26] Lar Pláticos. 2018. Disponível em: $<$ http://larplasticos.com.br>. Acesso em: 2 maio 2018.

[27] Silva ,José Nazareno Santos. Federal. Siderurgia. e-Tec Brasil, Belém do Pará, PA, p. 1-110, jan. 2010. Disponível em: <http://estudio01.proj.ufsm.br/cadernos/ifpa/tecnico_metalurgica/ siderurgia.pdf >. Acesso em: 14 abr. 2018.

[28] Empresa Prestadora De Serviço Para O Setor Industrial (Informações pessoais), 2018.

[29] Ventura, Magda Maria. O estudo de caso como modalidade de pesquisa. Revista da Sociedade de Cardiologia do Estado do Rio de Janeiro, Rio de Janeiro, v. 20, n. 5, p. 383-386, set./out. 2007. Disponível em: <http://sociedades.cardiol.br/socerj/revista/2007_05/a2007_v20_n 05_art10.pdf>. Acesso em: 10 maio 2018.

[30] Marconi, Marina de Andrade; Lakatos, Eva Maria. Metodologia do trabalho científico. São Paulo: Atlas, 2011. 225.

[31] Dantas, Rosana Aparecida Spadoti; Sawada, NamieOkino; Malerbo, Maria Bernadete. Pesquisa Sobre Qualidade de Vida, Revisão da Produção Científica das Universidades Públicas de São Paulo. Latino-am Enfermagem, São Paulo, v. 11, n. 4, p. 532-538, jul. 2003. Disponível em: <http://www.scielo.br/pdf/rlae/v11n4/v11n4a17>. Acesso em: 02 maio 2018.

[32] Milanez, Bruno; Porto, Marcelo Firpo de Souza. Gestão Ambiental E Siderurgia: Limites E Desafios No Contexto Da Globalização. 1. ed. [S.1.: s.n.], 2009. 4-21 p. v. 3. Disponível em: < https://rgsa.emnuvens.com.br/rgsa/article/view/113 >. Acesso em: 09 out. 2018.

[33] Universidade Federal De Santa Catarina. 2018. Disponível em: 〈https:// portalvirtuahab.paginas.ufsc.br/aco>. Acesso em: 18 nov. 2018.

[34] Spink, Peter Kevin. Pesquisa de Campo em Psicologia Social: Um Perspectiva Pós-Constitucionalista. Psicologia \& Sociedade, São Paulo, p. 18-42, jul. 2003. Disponível em: <http://www.scielo.br/pdf/psoc/v15n2/a03v15n2>. Acesso em: 07 abr. 2018.

[35] Peixoto, Danilo et al. Fabricação do Ferro Gusa e do Aço. Disponível em: <http://www.ifba.edu.br/metalografia/arq/gusa.pdf>. Acesso em: 08 out. 2018 .

[36] Botelho, Vitor. Preparação da Carga Metálica. 2011. Disponível em: <https://literaturamecanica.wordpress.com/2011/06/17/preparacao -da-carga-metalica-2/>. Acesso em: 09 out. 2018.

[37] Arcelormittal, Material que sobra no processo de produção do aço é transformado em insumo para a produção de cimento, pavimentação de estradas e fertilizantes. 2014. Disponível em: <https://economia.ig.com.br/empresas/industria/arcelormittalbrasi 1/2014-10-15/destino-nobre-para-residuos-do-aco.html>. Acesso em: 08 nov. 2018.
[38] VALE, Índices de minério de ferro. 2018. Disponível em: <http://www.vale.com/brasil/PT/business/mining/iron-ore-

pellets/Paginas/Iron-Ore-Indices.aspx>. Acesso em: 25 out. 2018.

[39] Martins, Sebastião Venâncio. Recuperação de Áreas Degradadas. Ações em Áreas de Preservação Permanente, Voçorocas, Taludes Rodoviários e de Mineração. Editora Aprenda Fácil. Edição: 1. P. 1 - 270, 2014.

[40] Bitar, Omar Yazbek. Avaliação de Recuperação de Áreas Degradadas por Mineração na Região Metropolitana de São Paulo. 1997. 184 p. Tese (Doutorado em Engenharia Mineral)- Escola Politecnica, Universidade de São Paulo, São Paulo, 1997.

[40] Nunes, Rodrigo Rodrigues; Silva, Ricardo Antônio Pereira da. Transbordo de Resíduos Sólidos. Revista Pensar Engenharia, [S.1.], v. 3, n. 1, p. 1-18, jan. 2015. Disponível em: <http://www.ufjf.br/engsanitariaeambiental/files/2012/09/ARTIG O_Esta\%C3\%A7\%C3\%A3o-de-transbordo.pdf $>$. Acesso em: 02 nov. 2018.

[41] Jacobi, Pedro Roberto; Besen, Gina Rizpah. Gestão de resíduos sólidos em São Paulo: desafios da sustentabilidade: Sustentabilidade urbana e redução de resíduos. Estudos Avançados, [S.1.], v. 71, n. 25, p. 135-158, jan. 2011. Disponível em: <http://www.scielo.br/pdf/ea/v25n71/10>. Acesso em: 20 nov. 2018.

[42] Matos, Francinaldo Oliveira et al. Impactos Ambientais Decorrentes de Aterros Sanitários da Região Metropolitana de Belém PA: Aplicação de ferramentas de Melhoria Ambiental. Caminhos de Geografia, Uberlândia, v. 12, n. 39, p. 297-305, set. 2011.

[43] Farias, Carlos Eugênio Gomes. Mineração e Meio Ambiente no $\quad 2002.2$ Disponível em: <http://www.mma.gov.br/estruturas/sqa_pnla/_arquivos/minera.p df>. Acesso em: 23 out. 2018.

[44] Dias, Elvira Gabriela Ciacco da SIlva. Avaliação de Impacto Ambiental de Projeto de Mineração no Estado de São Paulo: a etapa de Acompanhamento. 2001. 283 f. Tese (Doutorado em Engenharia)- Escola Politecnica, Universidade de São Paulo, São Paulo, 2001. Disponível em: <http://file:///C:/Users/Igor/Downloads/Elviradias.pdf>. Acesso em: 23 out. 2018.

[45] BACEN - Banco Central do Brasil, Cotações e boletins. 2018. Disponível em: <https://www.bcb.gov.br/acessoinformacao/legado?url=https:\%2 F\%2Fwww4.bcb.gov.br\%2Fpec\%2Ftaxas\%2Fport\%2Fptaxnpesq. asp \%3Fid\%3Dtxcotacao\%26id\%3Dtxcotacao>. Acesso em: 10 ago. 2019.

[46] FEAM - Fundação Estadual do Meio Ambiente, Inventário de Resíduos Sólidos Industriais. 2018. Disponível em: <http://www.feam.br/declaracoes-ambientais/inventario-deresiduos-solidos-industriais $>$. Acesso em: 10 ago. 2019. 